\title{
Chronic Obstructive Pulmonary Disease and Asthma Differentiation by Immunologic Features
}

\author{
Natalya Avtandilovna Raspopina ${ }^{1,2, *}$, Shuganov Evgeny Grigoryevich ${ }^{2}$, \\ Salmasi Jean Mustafaevich ${ }^{3}$, Shuganov Altxander Evgenyevich ${ }^{2}$, Popova Elena Nikolaevna ${ }^{1}$, \\ Subbotina Tatyana Igorevna ${ }^{1}$, Filippova Tamara Vladimirovna ${ }^{1}$ \\ ${ }^{1}$ Institute of Clinical Sciences, Sechenov First Moscow State Medical University of Ministry of Health of Russia (Sechenov University), \\ Moscow, Russia \\ ${ }^{2}$ Department of Therapy, State Budgetary Institution Moscow Regional Research and Clinical Institute n. a. M. F. Vladimirsky. Moscow, \\ Russia \\ ${ }^{3}$ Pirogov Russian National Research Medical University (RNRMU) of Ministry of Health of Russia, Moscow, Russia
}

\section{Email address:}

raspopina_nataly@mail.ru (N. A. Raspopina)

${ }^{*}$ Corresponding author

\section{To cite this article:}

Natalya Avtandilovna Raspopina, Shuganov Evgeny Grigoryevich, Salmasi Jean Mustafaevich, Shuganov Altxander Evgenyevich, Popova Elena Nikolaevna, Subbotina Tatyana Igorevna, Filippova Tamara Vladimirovna. Chronic Obstructive Pulmonary Disease and Asthma Differentiation by Immunologic Features. American Journal of Internal Medicine. Vol. 9, No. 3, 2021, pp. 148-152.

doi: 10.11648/j.ajim.20210903.17

Received: April 25, 2021; Accepted: May 18, 2021; Published: June 7, 2021

\begin{abstract}
Among respiratory diseases, asthma and chronic obstructive pulmonary disease (COPD) are the most common. Considering that the leading clinical symptom of these diseases is bronchial obstruction, as well as a large number of phenotypes in both asthma and COPD, especially when patients have signs of both diseases, problems arise in differential diagnosis. Immune inflammation plays an important pathological role in chronic obstructive pulmonary disease and asthma. Lymphocyte is the principal immune cell capable of recognizing a particular molecular determinant of the organic structure disorder. We aimed to search for specific features of the immune response in these diseases. Therefore, we determined in peripheral blood the relative and absolute content of lymphocytes expressing the CD3, CD4, CD16, CD54, CD56, CD72, HLA-DR, CD95, and CD178 antigens. The study found that low CD8, CD16 and high CD 178 lymphocytes are characteristic of patients with asthma, and high CD8, CD16 and low CD 178 are typical in COPD. Over 4-5 times increase in CD54 is characteristic of asthma, while in COPD the index exceeded the norm by only 50\%. An important feature of COPD is a low apoptosis irrespective of the stage of the disease. These immunologic features can be additional criteria for asthma and COPD differentiation.
\end{abstract}

Keywords: Asthma, Chronic Obstructive Pulmonary Disease, Differential Diagnosis, Immune Inflammation, Cytotoxic Lymphocytes, CD Antibodies

\section{Introduction}

Among respiratory diseases, asthma and chronic obstructive pulmonary disease (COPD) are the most common Worldwide, over 300 million people suffer from asthma and COPD is the 3rd cause of fatal outcomes by $2020[1,2]$. Bronchial obstruction syndrome is the leading clinical feature of both diseases. Their specific features allow a simple differential diagnosis in most cases, especially at early stages $[2,3]$. However, the diagnosis is complicated considering the variety of asthma and COPD phenotypes and combination of signs of both diseases is several patients (smoking in asthma, high sputum eosinophilia, over 12\% FEV1 increment on bronchodilator test in COPD, etc.). In recent years, practical medicine has searched for biological markers, such as hydrogen peroxide, nitric oxide, and eosinophil mediators (e.g., eosinophilic cationic protein) in exhaled air to establish a correct diagnosis [3,4]. Nevertheless, developments are extremely urgently needed to clarify the diagnosis and differentiate COPD from asthma. 
We evaluated the lymphocyte surface antigens using monoclonal antibodies for differential diagnosis of COPD and asthma.

\section{Materials and Methods}

Sixty-eight patients were included: 22 COPD patients (mean age 55.2 \pm 1.4 years), 22 asthma patients (mean age $36 \pm 1.2$ years), and 24 clinically healthy blood donors (mean age $52.6 \pm 2.8$ years) as the control. Blood tests were performed in the exacerbation stage before prescription of glucocorticosteroids and antibiotics, and in clinically stable disease during 4 weeks without the use of hormones.

To determine the relative and absolute content of CD3, CD4, CD8, CD16, CD54, CD56, CD72, HLA-DR, CD95, and CD178 antigen-expressing lymphocytes in peripheral blood, we performed indirect immunofluorescence with ICO monoclonal antibodies (from Dako, eBioscience). As auxiliary methods, we isolated lymphocyte by Boyum in FicollVerografin density gradient, assessed their viability immediately after isolation from blood, and counted them in peripheral blood. The results were processed statistically to assess the reliability of the changes registered in large samples using $t$-test and in small samples with non-normal distribution as well as in pairwise comparing of related variants using Wilcoxon-Mann-Whitney nonparametric criterion.

\section{Discussion}

Immune inflammation develops as a specific body response to external stimuli and underlies the pathology of COPD and asthma. Lymphocyte is the leading cell of immune system, capable to recognize a particular molecular determinant that disturbs the integrity of organ structure. Two main subpopulations of lymphocytes are distinguished: Bcells producing antibodies, or immunoglobulins (Ig), that bind antigens, and T-cells and T-helpers, producing when activated a wide range of cytokines that control inflammation and immune response. Each of these cells carries on the surface membrane glycoproteins acting as co-receptors of intercellular interactions and being markers of quantitative and functional features of the cells. Thus, T-cell (CD3), helper-inducer (CD4), and suppressor-cytotoxic (CD8) lymphocytes subpopulations are divided $[5,6]$. The CD3 antigen is a component of a membrane-associated structure, the so-called antigen-specific T-cell receptor (TcR/CD3) initiating antigen-dependent T-cell activation [7,8].

The CD4 and CD8 molecules, which recognize structural determinants of class II and class I antigens of the major histocompatibility complex respectively, provide the immunological restriction process and can transmit the T-cell activating signal without TcR/CD3 involvement $[6,8,9]$. Regulatory cells $(\mathrm{CD} 4+)$ regulate the other cells in the immune response progress. They stimulate immune cells by producing lymphokines [7, 10], which realize most of the B-cells functions $[8,10,11]$. The main function of CD8 cells is cytotoxicity; they are killer cells, acting by direct cytolysis of cellular structures affected by antigen-induced immunological reaction $[5,12]$. Cells are destructed by complete or partial cell dissolution; thus, CD8 cells play a leading role in antiviral, antitumor, and transplant immunity $[6,7,8]$. We used $\mathrm{CD} 4 / \mathrm{CD} 8$ ratio, an immunoregulatory index, to assess the nature of the processes. Donors in our study showed the ration equal to $1.42 \pm 0.04$.

A significant decrease of CD3 cells (in both stages of the disease) was noted in asthma patients. The cause was the decrease of both CD4 and CD8 resulted in a significant increase of $\mathrm{CD} 4 / \mathrm{CD} 8$ immunoregulatory index up to $1.65 \pm 0.005(\mathrm{p}<0.001)$ (Table 1).

Table 1. Peripheral blood lymphocyte populations and subpopulations in various stages of asthma and COPD (\%).

\begin{tabular}{|c|c|c|c|c|c|c|}
\hline \multirow[b]{2}{*}{$\begin{array}{l}\text { Lymphocyte } \\
\text { population }\end{array}$} & \multirow[b]{2}{*}{ Markers } & \multirow[b]{2}{*}{$\begin{array}{l}\text { Healthy blood } \\
\text { donors }\end{array}$} & \multicolumn{2}{|l|}{ Asthma patients $(n=49)$} & \multicolumn{2}{|c|}{ COPD patients $(n=37)$} \\
\hline & & & Acute stage $(n=27)$ & $\begin{array}{l}\text { Controlled } \\
\text { disease }(n=22)\end{array}$ & Acute stage $(n=22)$ & $\begin{array}{l}\text { Stable disease } \\
(n=15)\end{array}$ \\
\hline \multirow{3}{*}{ T-cells } & CD3 & $65.20 \pm 0.66$ & $56.64 \pm 1.72^{* *}$ & $50.52 \pm 1.02^{*}$ & $61.95 \pm 2.95$ & $52.28 \pm 2.26^{* *}$ \\
\hline & CD4 & $36.48 \pm 0.95$ & $33.42 \pm 0.73^{* *}$ & $32.96 \pm 0.53^{* * *}$ & $32.60 \pm 0.71^{* * *}$ & $37.86 \pm 2.61$ \\
\hline & CD8 & $25.90 \pm 0.50$ & $20.69 \pm 0.73^{*}$ & $18.81 \pm 0.27^{*}$ & $36.23 \pm 2.54^{*}$ & $32.92 \pm 1.96^{* *}$ \\
\hline \multirow{2}{*}{ NK cells } & CD16 & $13.22 \pm 0.43$ & $9.73 \pm 0.33^{*}$ & $12.41 \pm 0.74$ & $25.24 \pm 3.16^{*}$ & $22.11 \pm 1.07^{*}$ \\
\hline & CD56 & $4.47 \pm 0.09$ & $15.58 \pm 1.14^{*}$ & $9.57 \pm 0.55^{*}$ & $22.18 \pm 2.13^{*}$ & $17.94 \pm 1.99^{* *}$ \\
\hline
\end{tabular}

The data are presented as the arithmetic mean $(\mathrm{M})$ with the standard error of the mean $( \pm \mathrm{m})$.

$* \mathrm{p}<0.001 ; * * \mathrm{p}<0.01 ; * * * \mathrm{p}<0.05$ (compared with healthy people).

In COPD patients, CD3 T-cells decreased in both stages of the disease, more in stable stage (Table 1). The CD4 decreased during exacerbation and increased above the established norm during stable in COPD with the accompanying significant increase in CD8 (the CD4/CD8 index did not exceed 1.15 even in stable disease). This indicates the predominantly cytotoxic mechanisms of the immune system action manifested by excessive T-cells stimulation [5, 12-14]. Our study has shown that this process in COPD does not depend on the stage of the disease (Table 1).

NK cells, a type of T-cells, play a significant role in the development of inflammation and are the first to "tune up" to protect the body against foreign and altered cells [10, 12, 14]. The CD 16 surface receptor markers the total NK cells blood count. The CD56 antigen reflects their activity $[15,16]$. NK cells perform an antigen-specific effector immune reaction of antibody-dependent cellular cytotoxicity. NK cells function similar to T-cytotoxic lymphocytes but recognize target cells only bound to antibodies [16]. NK cells also participate in antibody-dependent cell-mediated cytolysis through the surface Fc-fragment of IgG (CD16) receptor [14, 15].

The NK cells (CD16) blood content was found to be low 
both in controlled and exacerbate asthma but CD56 NK cells predominated (Table 1) especially in the disease exacerbation.

An increase in the NK cells was also observed in COPD both in controlled and acute stages (Table 1). Active NK cells (CD56) also prevailed, similar to those in asthma. They are exhausted in controlled in asthma but remain the same in COPD.

Given the NK cells (CD56) high activity and antimicrobial function one can suppose an important role for airway infection in maintaining the inflammatory response in COPD $[15,16]$. Infected cells are more susceptible to lysis by NK cells than uninfected ones $[17,18]$.

The last marker we investigated is the adhesion receptor CD54 (ICAM-1) reflecting the readiness of cells to migrate into the tissue and their interaction with antigen-presenting cells [10].

Normally, CD54 adhesion receptors are present in low concentrations on the membranes of leukocytes and endothelial cells. When stimulated by cytokines IL-1, TNF-a, INF-g, IL-1, or LPS, ICAM-1 expression on the cytoplasmic membrane increases dramatically. ICAM-1 is a ligand of the LFA-1 integrin receptor found on leukocytes, which bind to the endothelium via the ICAM complex upon activation [8].

Immunological processes involving ICAM-1 (CD54) adhesion molecules related to the integrin receptor activate lymphocytes. They increase the lymphocytes ability to migrate to the inflammation focus and participate in contact interactions with antigen-presenting cells $[11,20]$.

Our data indicate a significant (more than 2-fold) increase in the level of lymphocytes carrying ICAM adhesion receptors (CD54) in peripheral blood of patients with COPD and asthma, during both exacerbation and controlled disease. ICAM-1 expression is increased under the influence of cytokines: IL-1, TNF-a, INF-g, IL-1, and LPS, which have destructive effects on bronchial and lung tissue (20). Therefore, we can assume that increased ICAM-1 is one of the indirect evidences of persistent destructive process in lungs, bronchial walls, and vessels in COPD and asthma patients $[8,12,16]$. Thus, we did not observe any significant differences of T-cells activation and differentiation markers to differentiate COPD and asthma.

However, we obtained important results when studying markers of lymphocyte readiness to trigger activation apoptosis.

Apoptosis is a natural completion of the immune response aimed at removal of cells that have fulfilled their protective function and restoration of the initial state of the immune system $[5,8]$. In a number of immunopathological diseases, induction of the activation process is impaired accompanied by a steady progression of inflammation $[11,20]$. To confirm this statement, we assessed the blood content of lymphocytes expressing CD95, Fas-dependent apoptosis induction receptor, and CD178, ligand to this receptor [18, 19].

Considering the Fas-dependent apoptosis induction system, the lymphocytes expressing Fas-antigen CD95 are increased in controlled asthma compared to healthy people, while controlled disease low during the asthma exacerbation (Table 2). In COPD patients, however, the blood CD95-lymphocyte content was more than three times higher than in healthy people regardless of the stage of the disease

Apparently, this is associated in COPD with a high blood concentration of various cytotoxic lymphocytes releasing mediators inducing apoptosis, including Fas (CD95) expression on the cell surface [9]. The blood content of lymphocytes carrying Fas ligand (CD178) on their surface was significantly increased in asthma patients, while in COPD patients it was 2 times lower than in healthy people (Table 2). The CD95 lymphocytes expression is known to reflect the lymphocytes readiness to enter into apoptosis, that is, to activate the programmed cell death by the Fasdependent mechanism [9, 19]. The study revealed that in COPD patients, regardless of the period of the disease (exacerbation or stable disease), the readiness of lymphocytes to initiate apoptosis is high (Table 2).

Table 2. Characteristics of peripheral blood lymphocytes activation markers in various stages of asthma and COPD (\%).

\begin{tabular}{|c|c|c|c|c|c|}
\hline \multirow[b]{2}{*}{ Markers } & \multirow{2}{*}{$\begin{array}{l}\text { Healthy blood } \\
\text { donors }\end{array}$} & \multicolumn{2}{|l|}{ Asthma patients $(n=49)$} & \multicolumn{2}{|c|}{ COPD patients $(n=37)$} \\
\hline & & Acute stage ( $\mathbf{N}=\mathbf{2 7})$ & $\begin{array}{l}\text { Controlled disease } \\
(\mathrm{N}=22)\end{array}$ & Acute stage $(\mathrm{N}=22)$ & $\begin{array}{l}\text { Stable disease } \\
(\mathrm{N}=15)\end{array}$ \\
\hline CD54 & $5.55 \pm 0.33$ & $\begin{array}{l}27.92 \pm 1.55 \\
\mathrm{p}<0.001\end{array}$ & $\begin{array}{l}26.29 \pm 0.69 \\
\mathrm{p}<0.001\end{array}$ & $\begin{array}{l}15.91 \pm 2.79 \\
\mathrm{p}<0.001\end{array}$ & $\begin{array}{l}15.56 \pm 2.31 \\
\mathrm{p}<0.001\end{array}$ \\
\hline CD95 & $4.42 \pm 0.20$ & $3.74 \pm 0.68$ & $\begin{array}{l}7.74 \pm 0.32 \\
\mathrm{p}<0.01\end{array}$ & $\begin{array}{l}15.04 \pm 1.06 \\
\mathrm{p}<0.001\end{array}$ & $\begin{array}{l}13.64 \pm 1.84 \\
\mathrm{p}<0.01\end{array}$ \\
\hline CD178 & $9.22 \pm 1.04$ & $\begin{array}{l}13.85 \pm 1.09 \\
\mathrm{p}<0.01\end{array}$ & - & $\begin{array}{l}4.82 \pm 2.34 \\
\mathrm{p}<0.05\end{array}$ & - \\
\hline $\mathrm{CD} 25 / \mathrm{CD} 95$ & $1.43 \pm 0.06$ & $\begin{array}{l}3.17 \pm 0.45 \\
\mathrm{p}<0.01\end{array}$ & $\begin{array}{l}1.20 \pm 0.08 \\
\mathrm{p}<0.05\end{array}$ & $1.05 \pm 0.13$ & $1.00 \pm 0.19$ \\
\hline HLA-DR \CD95 & $3.04 \pm 0.33$ & $\begin{array}{l}5.23 \pm 0.64 \\
\mathrm{p}<0.01\end{array}$ & $\begin{array}{l}1.75 \pm 0.01 \\
\mathrm{p}<0.01\end{array}$ & $\begin{array}{l}1.95 \pm 0.14 \\
\mathrm{p}<0.01\end{array}$ & $\begin{array}{l}1.14 \pm 0.49 \\
\mathrm{p}<0.01\end{array}$ \\
\hline
\end{tabular}

The data are presented as the arithmetic mean (M) with the standard error of the mean $( \pm \mathrm{m})$.

${ }^{*} \mathrm{p}<0.001 ;{ }^{* *} \mathrm{p}<0.01 ; * * * \mathrm{p}<0.05$ (compared with healthy people).

The immune response inhibition is possible by removing the activated autoreactive lymphocytes through the Fas (CD95) and FasL (CD178) interaction [14]. According to our data, in the COPD exacerbation the Fas (CD 95) increases, but the FasL (CD178) content does not exceed $4.82 \pm 2.34 \%$ $(9.22 \pm 1.04$ in the control). In asthma patients, Fas (CD95) was lower during exacerbation than in the control, and FasL (CD178) increased to $13.85 \pm 1.09 \%$. 
To assess changes in the immune system, priority is given not to the absolute number of lymphocytes expressing specific lymphocyte markers but to changes in lymphocyte functional activity associated with the ratio of markers in the population. In this regard, the CD25/CD95 and HLADR/CD95 ratios were evaluated [10]. Elevation of the CD25/CD95 ratio indicates a predominance of lymphocyte activation followed by proliferation over their readiness for Fas-mediated apoptosis, while a parallel increase in the HLA-DR/CD95 ratio reflects a predominance of cell differentiation over their elimination. According to the data obtained, in the asthma controlled these ratios decreased indicating the predominance of activation apoptosis and the "inhibition" of the immune response [9], and in the exacerbation they increased reflecting the activity of the immunological process.

COPD patients showed no change in CD25/CD95 ratio regardless of disease stage, and the HLA-DR/CD95 ratio was lower than in healthy individuals. This seems to be related to the high blood CD95 lymphocytes characteristic of immune system activation $[5,20]$ in COPD and a lower lymphocyte apoptosis than in asthma because of the low content of lymphocytes expressing FasL (CD178).

\section{Conclusions}

The data obtained allowed us to identify the characteristic immunological features of COPD and asthma and differentiate the diseases by the T-cell subpopulations quantification and the peripheral blood cells activation markers. Thus, patients with asthma have low blood content of CD8, CD16 lymphocytes contrast to the high content in COPD (compared with the control group). The blood CD178 lymphocytes content is high in asthma while low in COPD. An increase in CD54 by a factor of more than 4-5 compared to the norm is typical for asthma, while in COPD this increase is much more modest and does not exceed 50\% (Figure 1). An important feature of COPD is a low level of apoptosis regardless of the stage of the disease.

\begin{tabular}{|l|c|c|c|c|c|}
\hline \multirow{2}{*}{ Disease } & \multicolumn{5}{|l|}{ Surface markers of lymphocytes } \\
\cline { 2 - 6 } & CD 8 & CD 16 & CD 178 & CD 54 & \\
\hline COPD & $\uparrow$ & $\uparrow$ & $\downarrow$ & $\uparrow$ & $\begin{array}{l}\text { Low level of } \\
\text { apoptosis regardless } \\
\text { of the disease stage }\end{array}$ \\
\hline Asthma & $\downarrow$ & $\downarrow$ & $\uparrow$ & $\uparrow \uparrow$ & \\
\hline
\end{tabular}

Figure 1. COPD and asthma differentiation based on lymphocyte immunological activity.

These immunologic features can be additional criteria for asthma and COPD differentiation.

\section{Recommendations}

Irrespective of the clinical activity, COPD can be differentiated from asthma by the increased number of CD8, CD16, CD54, while asthma is accompanied by the decrease in CD8, CD16, with a significant increase in lymphocytes with CD54 adhesion receptor and, to a lesser extent, CD178. In COPD, low level of apoptosis can predict the persistent course of the disease requiring the prolonged therapy.

\section{Abbreviations}

CD4 - a marker of T-helpers

CD8 - a transmembrane glycoprotein serving as a coreceptor of T-cell receptors

CD4 / CD8 - immunoregulatory index.

CD16 - low affinity receptor for the Fc fragment of IgG III

CD 54 (ICAM-1), CD23, CD 95L (CD 178) - functional activation markers of lymphocytes.

CD 56 - neutral cell adhesion molecule

CD72 - common B-cell marker

COPD - chronic obstructive disease
FasL - surface lymphocyte receptors.

Fas / Apo1 - a membrane receptor glycoprotein.

FEV1 - a forced expiratory volume in the first second.

HLA-DR, CD95 - differentiation activation antigens.

$\mathrm{mIg}$, - immunoglobulin

IL-1 - interleukin -1

LFA-1 - integrin receptor ligand

LPS - lipopolysaccharide

NK - lymphocytes - "natural" killer cells.

TcR / CD3 - antigen-specific T-cell receptor

Th2 - a subpopulation of T-helper lymphocytes.

TNF4 - tumor necrosis factor - 4 .

TNF $\alpha$ - tumor necrosis factor $\alpha$.

$\mathrm{Ab}$, antibodies.

Ig, immunoglobulin.

mIg, membrane-bound immunoglobulins.

COPD, chronic obstructive pulmonary disease.

\section{Acknowledgements}

The authors are grateful to Kazemirsky AN, Professor of the Department of Pathophysiology of the N. I. Pirogov Russian National Research Medical University, for assistance in immunological research, and to Dr. Vitalii Dengin for his assistance in the processing of the manuscript. 


\section{References}

[1] Aysanov Z. R., Avdeev S. N., Arkhipov V. V., Belevsky A. S., Leshchenko I. V., Ovcharenko S. I., Shmelev E. I., Chuchalin A. G. National clinical guidelines for the diagnosis and treatment of COPD: an algorithm for making clinical decisions. Pulmonology 2017; 27 (1): 13-20. (In Russ)] https://doi.org/10.18093/0869-0189-2017-27-1-13-20.

[2] Global Strategy for Asthma Management and Prevention. Revised 2018 // www.ginasthma.com.

[3] Anaev E. Kh.. Biological Markers of Chronic Obstructive Pulmonary Disease. Practical pulmonology 2018: 1: 26-31. http://atmosphere-ph.ru (In Russ).

[4] Vijverberg SJ, Hilvering B, Raaijmakers JA, Lammers JW, der Zee AH, Koenderman L. Clinical utility of asthma biomarkers: from bench to bedside. Biologics: Targets and Therapy 2013: 7 199-210. https://doi.org/10.2147/BTT.S29976.

[5] Raspopina N. Ah. Shukanov A. E., Paleev F. N., Salmasi Zh. M., Kazimir A. N. The role of cytotoxic lymphocytes in inflammation in COPD patients in the stage of exacerbation and remission. Almanac of clinical medicine. 2014; 35, 49-53. (In Russ) https://doi.org/10.18786/2072-0505-2014-35-49-53.

[6] Poryadin G. V., Salmasi Zh. M., Makarkov A. I. «Mechanism of regulation of expression of surface structures of differentiated lymphocyte. Immunology. 1997: 3: 4-8. (In Russ).

[7] Nikoletta Rovina, Antonia Koutsoukou, Nikolaos G. Koulouris. Inflammation and Immune Response in COPD: Where Do We Stand?. Mediators of Inflammation vol. 2013 on p. 1- 9., Article ID 413735 https://doi.org/10.1155/2013/413735.

[8] Won-Dong Kim, Hyun-Sook Chi, Kang-Hyeon Choe, YeonMok Oh, Sang-Do Lee, Kyu-Rae Kim, Kwang-Ha Yoo, David A. Ngan, W. Mark Elliott, David J. Granville, Don D. Sin, James C. Hogg A possible role for CD8+ and non-CD8+ cell granzyme B in early small airway wall remodelling in centrilobular emphysema," Respirology, vol. 18, no. 4, pp. 688-696, 2013. https://doi.org/10.1111/resp.12069.

[9] Poryadin G. V., Salmasi Zh. M., Kazimirsky A. N. Comparative characteristics of markers of Fas-dependent apoptosis in patients with bronchial asthma and COPD. Russian journal of immunology, 2013: 7 (2-3), 207 (In Russ).

[10] Poryadin G. V., Salmasi Zh. M., Kazimirsky A. N., Semenova L. Yu. Immunopathogenesis of atopic diseases. Bulletin of Siberian medicine 2017; 16 (4): 233-241. (In Russ)] https://doi.org/10.20538/1682-0363-2017-4-233-241.
[11] Chapman K. R., Boulet L. P., Rea R. M., Franssen E. Supoptimal asthma control: prevalence detection and consequence in general practice. Eur. Respir. J. 2008; 31 (2): 320-325 https://doi.org/10.1183/ 09031936. 00039707.

[12] Culley F. J. Natural killer cells in infection and inflammation of lung. //Immunology. 2009, 128 (2): 51-163. https://doi.org/10.1111/j.1365-2567.2009.03167.x.

[13] Poryadin G. V., Orsanco M. A., Salmas J. M., Kazimirsky A. N. "Activation processes in lymphocytes of patients with latent sensitization", "Pathological physiology and experimental therapy". 2009: 1, 23-24 (In Russ) https://doi.org/10.21518/2079-701x-2019-8-76-82.

[14] Polverino F, Baraldo S, Bazzan E, Agostini S, Turato G, Lunardi F, Balestro E, Damin M, Papi A, Maestrelli P, et al. A novel insight into adaptive immunity in chronic obstructive pulmonary disease: $\mathrm{B}$ cell activating factor belonging to the tumor necrosis factor family. Am J Respir Crit Care Med 2010; 182: $\quad$ 1011-1019.

DOI: https://doi.org/10.4049/jimmunol.172.8.4661.

[15] Culley F. J. Natural killer cells in infection and inflammation of lung. Immunology. 2009, 128 (2): 51-163. https://doi.org/10.1111/j.1365-2567.2009.03167.x.

[16] Folli C., Chiappori A., Pellegrini M., Garelli V., Riccio A. M. et al «COPD treatment: real life and experimental effects on peripheral NK cells, their receptors expression and their INF-y secretion. Pulm. Pharmacol. Ther. 2012; 25 (5): 371-6. https://doi.org/10.1016/j.pupt.2012.06.009.

[17] Rijivec M., Volarevic S., Osolnik K., Korosec P. Natural killer $\mathrm{T}$ cell in pulmonary disorders. Respir. Med., 2011, 105 Suppl 1 S20-5. https://doi.org/10.1016/s0954-6111(11)70006-3.

[18] Katchar K, Wahlstron A., Soderston J., Eklund J. Характеристика естественных киллеров и CD 56 T клеток у пациентов с саркоидозом. Eur. Respir. J. 2005; 26: 77-85. [K. Katchar, Wahlstron A., Soderston J., Eklund J. Characterization of natural killer cells and CD $56 \mathrm{~T}$ cells in patients with sarcoidosis. Eur. Respir. J. 2005; 26: 77-85.] https://doi.org/10.1183/09031936.05.00030805.

[19] Kongning Li, Deng Wu, Xi Chen, Ting Zhang, Lu Zhang, Ying Yi, Zhengqiang Miao, Nana Jin Xiaoman Bi, Hongwei Wang, Jianzhen $\mathrm{Xu}$, and Dong Wang. Current and Emerging Biomarkers of Cell Death in Human Disease. BioMed Research International Volume 2014, Article ID 690103, 10. http://dx.doi.org/10.1155/2014/690103.

[20] Ji Heui Kim and Yong Ju Jang Role of Natural Killer Cells in Airway Inflammation. Allergy Asthma Immunol Res. 2018 Sep; $10 \quad$ (5): $\quad 448-456 . \quad$ http://dx.doi: 10.4168/aair.2018.10.5.448. 